\title{
RESEÑAS BIBLIOGRÁFICAS
}

Teoría del hombre, por Francisco Romero. Biblioteca Filosófica, Editorial Losada, S. A., Buenos Aires, 1952.

findice de la obra: Primera parte. La intencionalidad. Capítulo I: La conciencia intencional. 1. Psiquismo preintencional y conciencia intencional; 2. Precedencia de lo cognoscitivo; 3. La intencionalidad y el juicio; 4. Inteligencia y signo objetivo; 5 . La intencionalidad como actividad; 6 . Intencionalidad e individualidad. Capítulo II: La comunidad humana como comunidad objetivante. Capítulo III : La cultura. a) Consideraciones preliminares; $b$ ) Cultura y comunidad; $c$ ) Cultura y naturaleza intacta; d) Cultura y naturaleza; e) $\mathrm{El}$ objeto de la cultura; f) Relaciones entre los objetos culturales; g) La objetivación cultural; $h$ ) Reacción de la cultura sobre el hombre. Capitulo IV: Yo y mundo. El hombre natural.

Segunda parte. El espíritu. Capítulo V: El espíritu en general. 1 , Intencionalidad y espíritu; 2. Espíritu y naturaleza. a) La totalidad; b) La realidad. Naturaleza y espíritu; $c$ ) Crítica de otras divisiones de la realidad. Ca. pítulo VI: Peculiaridad y significación del espíritu. 1. Notas del espiritu; 2. El espíritu como absoluto trascender; 3 . El espiritu en el cuadro de una metafisica de la trascendencia. Capítulo VII: Los valores. 1 . Sobre el valor en general; 2 . Sobre el valor teórico; 3 . Sobre el valor ético.

Tercera parte. El hombre. Capítulo VIII: Dualidad. Capítulo IX: Enmascaramiento, justificación y conciencia de sí. Capítulo X: Sociabilidad. Capítulo XI: Historicidad. Capítulo XII : Sentido.
Qué es la filosofía, por Francisco Romero. Editorial Columba, Buenos Aires, 1953.

Este opúsculo del célebre filósofo argentino pertenece a una colección editoral intitulada "Esquemas", y ha debido por ende ajustarse a los requerimientos que este nombre supone. Pero así como en una línea sola es discernible la im. pronta del gran pintor, otro tanto pue. de decirse de esta obra menor del gran maestro que nos ha dado tan señaladas obras mayores. Con trazo breve, pero siempre limpio y firme, hace el autor un inventario sucinto de las concepciones más prominentes de la filosofía en el curso de su historia; enumera en seguida, delineando escuetamente su contenido, las disciplinas filosóficas de mayor validez hoy en dia, y concluye, con la autoridad que le presta su vasta experiencia magisterial, dando ciertas orientaciones o consejos, que los principiantes encontrarán muy útiles, sobre la mejor manera de servirse de la bibliografía filosófica y de las llamadas Introducciones a la Filosofía, género, como se sabe, que tanto auge ha cobrado en la época contemporánea.

Creemos por nuestra parte que la porción mejor lograda de este ensayo es la consagrada a la enumeración y análisis esquemático de las diversas disciplinas filosóficas. Hay allí sin duda muchas sugestiones valiosas sobre las disciplinas tradicionales (lógica, meta. física, ética), sobre las modernas (teoría del conocimiento, filosofía de la historia, estética, axiología) y sobre las contemporáneas (filosofía de la religión, antropología filosófica, filosofía de la cultura).

Hubiera sido deseable tal vez que el autor nos dijera algo sobre la filosofia 